\title{
Increase in fertility rate before the age of 14 in Brazil from 1996 to 2018
}

\author{
Denise Leite Maia Monteiro ${ }^{1,2 *}$ (1) Fátima Regina Dias Miranda ${ }^{1,3}$ (1),

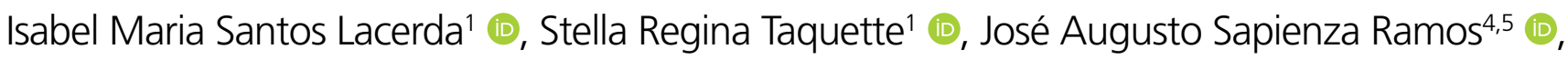 \\ Flavio Monteiro de Souza ${ }^{1}$ (1), Nádia Cristina Pinheiro Rodrigues ${ }^{6,7}$
}

\begin{abstract}
SUMMARY
OBJECTIVE: This study aimed to assess live birth frequency and age-specific fertility rates (ASFR) in the period 1996-2018 and the number of pregnancies at $<14$ years old in the period 2012-2018.

METHODS: This was a cross-sectional study conducted by search on Live Births Data System (SINASC/DATASUS) database.

RESULTS: There was a variation in ASFR in Brazil of $0.78 \%$ in 1996 to $0.87 \%$ in $2018(+11.5 \%)$. In the north region, it increased from $1.28 \%$ to $1.66 \%$ in 2018 . In the northeast region, it increased from $0.72 \%$ to $1.66 \%$ o $(+131 \%)$ in $1996-2011$, but decreased to $1.31 \%$ in 2018 (-21\% in relation to 2011). When comparing 1996 and 2018, in the southeast region, there was a $22 \%$ decrease; in the south region, it was 48.2\%; and in the Center-West region, it was 34\%; but in the north region, there was a $29.7 \%$ increase, and in the northeast region, it was $81.9 \%$. When adding girls who became pregnant aged 13 years and gave birth at 14 , there was a threefold increase in the rate.

CONCLUSIONS: The increase of pregnancies in <14 years old in less developed regions of Brazil shows an association with socioeconomic factors and reveals the severe problem of rape of vulnerable persons in the country.

KEYWORDS: Adolescent. Pregnancy. Rape. Sex offenses.
\end{abstract}

\section{INTRODUCTION}

Although the fertility rate in Brazil has decreased since 1960, it increased in the 1990s among adolescents, and from 2001 onward, there is a slow decrease.

The birth rate reduction was from $21.5 \%$ in 2006 to $18.1 \%$ in 2015 , motivated by the age group of 15-19 years in all the country's regions, with a stability tendency among mothers aged 10-14 years and a 5\% increase in the north region ${ }^{1}$.

Pregnancy in adolescence is more frequent in populations with low socioeconomic level, such as sub-Saharan Africa $(28 \%)^{2}$, and Latin America and the Caribbean present the second highest rate $(15 \%)$ of the total number of births ${ }^{3}$.

\footnotetext{
'Universidade do Estado do Rio de Janeiro - Rio de Janeiro (RJ), Brazil.

${ }^{2}$ Centro Universitário Serra dos Órgãos - Teresópolis (RJ), Brazil.

${ }^{3}$ Universidade do Grande Rio Professor José de Souza Herdy - Rio de Janeiro (RJ), Brazil.

${ }^{4}$ Universidade Federal do Rio de Janeiro, Instituto Alberto Luiz Coimbra de Pós-Graduação e Pesquisa de Engenharia - Rio de Janeiro (RJ), Brazil.

${ }^{5}$ Universidade do Estado do Rio de Janeiro, Centro de Geotecnologias - Rio de Janeiro (RJ), Brazil.

${ }^{6}$ Fundação Oswaldo Cruz, Escola Nacional de Saúde Sérgio Arouca - Rio de Janeiro (RJ), Brazil.

${ }^{7}$ Universidade do Rio de Janeiro, Instituto de Medicina Social - Rio de Janeiro (RJ), Brazil.

*Corresponding author: denimonteiro2@yahoo.com.br

Conflicts of interest: the authors declare there is no conflicts of interest. Funding: none.

Received on August 23, 2021. Accepted on August 24, 2021.
} 
This situation is aggravated when pregnancy occurs until 14 years old, with higher risks of maternal-fetal complications and social and psychological sequelae ${ }^{4}$. It is estimated that $2 \%$ of women in Latin America-Caribbean have their first childbirth before 15 years of age ${ }^{3}$.

On the other hand, data on pregnancy in girls aged $<13$ years are limited. Souto et al. ${ }^{5}$ studied the period $2011-$ 2015 and observed that 31,611 girls aged $\leq 13$ had children, especially in the northeast region $(39.4 \%)$, with a higher rate of unfavorable gestational outcomes in the group of rape notification ${ }^{5}$.

These pregnant girls are more susceptible to stress, emotional insecurity, preeclampsia, premature birth, postnatal complications, repeated pregnancies, and less prenatal consultations. Their children present a higher risk of low weight, mortality, hospitalizations, and emergency care ${ }^{3-5}$.

The objectives of this study were to evaluate the frequency of live births (LB) of mothers in the age group of $10-13$ years and the age-specific fertility rate (ASFR) in the period 1996-2018. There was also a calculation of the number of pregnancies initiated at $<14$ years old in the period 2012-2018, since pregnancy at this age constitutes a crime of rape of vulnerable .

\section{METHODS}

A cross-sectional epidemiological study was conducted through search on Live Births Data System (SINASC/ DATASUS) database in the period 1996-2018. Using the application TabWin and the scripts developed in Python language 3.8 version, 68.8 million registers were imported to the Database Management System (DBMS) opensource PostgreSQL 11.8 version.

Since SINASC registers all LB in the country, two groups of registers were selected for this study:

Group 1 (G1): Adolescents who had LB aged 10-13 years between 1996 and 2018.

Group 2 (G2): Adolescents who started pregnancy at 13 years old but delivered at 14 years old between 2012 and 2018 (selection from mother's age minus the number of full gestational weeks until childbirth).

It is noteworthy that SINASC database had its fields altered through time, more substantially between 2010 and $2012^{7}$. From 2012 onward, over $90 \%$ of LB registers received the attribute semagestac to calculate the mother's age at the start of pregnancy for G2.

The sum of occurrences of G1 and G2 results in the quantity of registers on SINASC that characterize rape of vulnerable, according to Art. 217-A of Federal Law nr. $12015^{6}$.
Although G1 represents girls $<14$ years at childbirth, the actual number of pregnancies starting at $<13$ years is underestimated due to the large ratio of adolescents who gave birth at 14 years but became pregnant at 13 years.

This study was developed using the following variables: birth according to mother's place of residence, birth according to region, and year of birth.

For the analysis of births in this age group in relative numbers, ASFR for G1 was calculated using as reference mother's age at childbirth. ASFR represents the mean number of LB/ woman in a specific age interval, presented per group of 1,000 women for each age group, according to Equation 1:

$A S F R \%_{10-13 ; \text {;rg.year }}=G 1_{\text {regy,year }} \cdot 1000 /$ FemPop $_{10-13 ; \text { reg.year }}$

where year $€\{1996,1997, \ldots, 2018\}$ is the reference year for data; reg $€\{\mathrm{BR}, \mathrm{CW}, \mathrm{NE}, \mathrm{N}, \mathrm{SE}, \mathrm{S}\}$ corresponds to Brazil (BR) or one of the five regions given as follows: Center-West $(\mathrm{CW})$, northeast $(\mathrm{NE})$, north $(\mathrm{N})$, southeast (SE) and south (S). ASFR\%o ${ }_{10-13 \text {;reg:year }}$ is the age-specific fertility rate for the interval 10-13 years old for a given region (reg) in a given year; $G 1_{\text {regyear }}$ is the frequency of G1 for a given region and year; and FemPop 10-13;regyear $_{\text {in }}$ is the total female population aged $10-13$ years in the region and year of reference.

For the sum $\mathrm{G} 1+\mathrm{G} 2$, a similar rate was calculated to $A S F R \% o_{10-13 \text {;reg:year }}$ denominated rape-related pregnancy rate according to legislation (RPRAL). Equation 2 shows the calculation, where year $\in\{2012,2013, \ldots, 2018\}$ :

$$
\begin{aligned}
& R P R A L \%_{10-13 ; r e g y \text { year }}= \\
& \left(G 1_{\text {reg;year }}+G 2_{\text {reg;year }}\right) \cdot 1000 / \text { FemPop }_{10-13 ; \text { reg;year }}
\end{aligned}
$$

For the variable FemPop 10-13;regyear the sources used were two population databases:

- Period 1996-2009: Demographic data available at DATASUS $^{8}$ website.

- Period 2010-2018: IBGE provides annual population projections considering the latest demographic census $(2010)^{9,10}$.

To obtain the measures to follow the evolution of ASFR and RPRAL in Brazil and its regions, the option was to calculate two percentage variations. The first is the percentage variation of $A S F R \%_{10-13 \text {;regyear }}$ and $R P R A L \%_{10-13 \text {;reg;year }}$ in relation to the same region $(\mathrm{reg})$ in the first year of the calculation of the respective rate, i.e., 1996 for ASFR and 2012 for RPRAL. Equation 3 exemplifies the calculation. For example, if a region $A$ presents $A S F R \% o_{10-13 ; A ; 1996}=0.6$ and $A S F R \% o_{10-13 ; A ; 2010}=0.9$, then $\operatorname{VarASFR} \%_{10-13 ; A ; 2010}=50 \%$. 
$\operatorname{VarASFR} \%_{10-13 ; \text {;eg;year }}=$

ASFR\% $\%_{10-13 ; \text { reg;year }} * 100 /$ ASFR $\%_{10-13 ; \text { reg; } 1996}-100$

The second percentage variation also relates ASFR and RPRAL rates of a given region and year in the function of the respective rate of the same year for Brazil. Thus, it measures the percentage difference of the rate of a region (CW, NE, N, SE, and $S$ ) in a given year in relation to the same period in Brazil. Equation 4 exemplifies the calculation of ASFR\%o ${ }_{10-13 ; \text { reg; year }}$ :

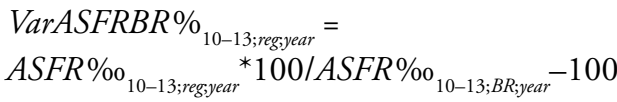

The research project was approved under the number CAAE 04209418.1.0000.5259.

\section{RESULTS}

In the period 1996-2018, there were 130,778 births from mothers aged 10-13 years in Brazil. In 1996, there was a variation on ASFR $\%{ }_{10-13 ; B R ; 1996}$ from $0.78 \%_{10-13 ; B R ; 1996}$ to $0.87 \%_{10-13 ; B R ; 2018}$, resulting in a percentage variation of $+11.5 \%$.

In the period 1996-2018, the ASFR in the $\mathrm{N}$ region varied from $1.28 \%_{10-13 ; N ; 1996}$ to $1.66 \%_{10-13 ; N ; 2018}$ with a peak of $1.99 \%_{10-13 ; N ; 2011}$ in 2011. The ASFR in the NE region increased from $0.72 \%_{10-13 ; N E ; 1996}$ to $1.66 \%_{10-13 ; N E ; 2011}$, showing a variation of $+131 \%$, but receding at the end of the series to $1.31 \%_{10}$ 13;NE;2018 (21\% reduction in relation to 2011$)$. CW and $S$ regions presented the highest ASFR at the beginning of the series, respectively, $1.44 \%_{10-13 ; C O ; 1996}$ and $0.83 \%_{10-13 ; 5 ; 1996}$ The SE region had the highest ASFR in $2003\left(0.64 \%_{10-13 ; S E ; 2003}\right)$, ending the series with $0.46 \%{ }_{10-13 ; S E ; 2018}$.

When comparing 1996 and 2018 (VarASFR\%), there was a $22 \%$ reduction in the SE region, $48.2 \%$ in the $S$ region, and $34 \%$ in the CW region; but there was a $29.7 \%$ and $81.9 \%$ increase in the ASFR in the $\mathrm{N}$ and $\mathrm{NE}$ regions, respectively $(\text { Table } 1)^{8-10}$.

Figure 1 shows the temporal evolution of $A S F R \%_{10-13 ; \text {;reg;year }}$ in Brazil and regions between 1996 and 2018. In the last years of the temporal series, it was verified that the SE and S regions composed the group with ASFR below the country's average; the $\mathrm{N}$ and $\mathrm{NE}$ regions presented an opposite relation; and the $\mathrm{CW}$ region was nearer to the country's rates.

Figure 1 also shows $A S F R \%_{10-13 \text {;reg;yar }}$ and the evolution of this rate with $\operatorname{VarASFR} \%_{10-13 ; \text { regivear }}$. It was verified that the $\mathrm{CW}$ and $S$ regions presented the most significant percentage reduction regarding 1996, whereas the NE region surpassed the $\mathrm{N}$ region, more than doubling ASFR in relation to 1996 between 2011 and 2013, but presented a reduction from then until 2018.
Data used in this study show a heterogenous population distribution across the territory. In 2018, Brazil had a population of 5,638,556 girls aged 10-13 years, with 2,234,368 $(39.6 \%)$ in the SE region; 1,528,044 (27.1\%) in the NE region; 747,171 (13.3\%) in the $S$ region; 664,832 (11.4\%) in the $\mathrm{N}$ region; and $484,141(8.6 \%)$ in the $\mathrm{CW}$ region. There was a decrease of $\operatorname{VarASFR} \%_{10-13 ; \text { reg; } 2018}$ in the three regions, including the most populated, but an $11.5 \%$ increase in ASFR in relation to 1996 .

When adding to ASFR results from 2012 onward the number of girls who became pregnant at 13 years of age and gave birth at 14 years (RPRAL), a 203.5\% increase was observed in relation to the data presented in Figure 1. On average, the rate was more than tripled when observing age $10-13$ at the start of pregnancy, instead of the mother's age at childbirth.

Table 2 shows the total number of adolescents in G1 and G2. When adding G2 to the analysis, it was verified that the number of pregnant girls aged 13 years was much higher, since in G2 over $60 \%$ of them became pregnant at 13 years, although in the official statistics they were counted as pregnant at 14 years old.

\section{DISCUSSION}

This is the first study on the temporal assessment of fertility rate in Brazil among the age group of 10-13 years. Outcomes show $11.5 \%$ increase in ASFR in the past 23 years. Another originality was the assessment of maternal age at conception, since statistics use a mother's age at childbirth as a criterion.

ASFR evaluation is a challenging task due to data scarcity and the country's development level ${ }^{4,5,11}$. This could be the main reason for the reduced number of publications about research on populations in the age group of 10-14 years, especially up to 13 years old.

On the other hand, data in this study show that ASFER increase in the age group of 10-13 years in Brazil is heterogenous and is concentrated in the $\mathrm{N}$ and $\mathrm{NE}$ regions. As the two regions present the country's lowest Human Development Index (HDI) 0.73 and $0.71^{12}$, respectively, there is an evident association with poverty and underdevelopment, as well as racism and low education level ${ }^{11}$. The association of inequalities and sexual violence is also verified worldwide, with the highest rates of pregnancy in adolescence in Africa, Central America, and South America $^{3}$. In Colombia, pregnancy as a consequence of violence reached $21.5 \%{ }^{11}$.

In the United States, declines in natality rates in the age group of 10-14 years were observed in the period 2000-2016, with greater falls after 2008 . There was a greater reduction among 13 years old, from 7.08 births/10,000 in 2000 to 1.80 in $2016^{13}$. 
Table 1. Distribution of age-specific fecundity rate in group 1 (10-13 years) per year and region of residence per 1,000 adolescents (ASFR\% $\left.{ }_{10-13 ; \text { reg;year }}\right)^{8-10}$

\begin{tabular}{|c|c|c|c|c|c|c|c|c|c|c|c|c|}
\hline \multirow[b]{2}{*}{ Year } & \multicolumn{2}{|c|}{ North } & \multicolumn{2}{|c|}{ Northeast } & \multicolumn{2}{|c|}{ Center-West } & \multicolumn{2}{|c|}{ Southeast } & \multicolumn{2}{|c|}{ South } & \multicolumn{2}{|c|}{ Brazil } \\
\hline & $\begin{array}{c}\text { B } \\
10-13\end{array}$ & ASFR\%o & $\begin{array}{c}\text { B } \\
10-13\end{array}$ & ASFR\%o & $\begin{array}{c}\text { B } \\
10-13\end{array}$ & ASFR\%o & $\begin{array}{c}\text { B } \\
10-13\end{array}$ & ASFR\%o & $\underset{10-13}{\text { B }}$ & ASFR\%o & $\begin{array}{c}\text { B } \\
10-13\end{array}$ & ASFR\%o \\
\hline 1996 & 727 & 10.28 & 1,617 & 0.72 & 670 & 1.44 & 1,568 & 0.59 & 777 & 0.83 & 5,359 & 0.78 \\
\hline 1997 & 809 & 10.38 & 1,825 & 0.81 & 585 & 1.22 & 1,525 & 0.57 & 702 & 0.74 & 5,446 & 0.78 \\
\hline 1998 & 823 & 10.37 & 2,063 & 0.9 & 647 & 1.33 & 1,595 & 0.59 & 730 & 0.76 & 5,858 & 0.83 \\
\hline 1999 & 892 & 10.46 & 2,110 & 0.91 & 587 & 1.18 & 1,631 & 0.59 & 671 & 0.69 & 5,891 & 0.82 \\
\hline 2000 & 909 & 10.52 & 2,175 & 1.00 & 598 & 1.26 & 1,508 & 0.58 & 668 & 0.72 & 5,858 & 0.86 \\
\hline 2001 & 948 & 10.54 & 2,228 & 1.01 & 596 & 1.23 & 1,476 & 0.55 & 671 & 0.71 & 5,919 & 0.86 \\
\hline 2002 & 868 & 10.38 & 2,438 & 1.09 & 544 & 1.1 & 1,426 & 0.53 & 646 & 0.68 & 5,922 & 0.85 \\
\hline 2003 & 995 & 10.56 & 2,183 & 0.97 & 557 & 1.11 & 1,740 & 0.64 & 600 & 0.62 & 6,075 & 0.86 \\
\hline 2004 & 1,072 & 10.64 & 2,063 & 0.91 & 557 & 1.09 & 1,237 & 0.45 & 608 & 0.62 & 5,537 & 0.77 \\
\hline 2005 & 1,081 & 10.59 & 2,182 & 0.94 & 560 & 1.05 & 1,519 & 0.53 & 600 & 0.60 & 5,942 & 0.80 \\
\hline 2006 & 1,096 & 10.58 & 2,333 & 0.99 & 589 & 1.08 & 1,445 & 0.50 & 584 & 0.58 & 6,047 & 0.81 \\
\hline 2007 & 1,224 & 10.92 & 2,427 & 1.23 & 577 & 1.16 & 1,442 & 0.57 & 575 & 0.63 & 6,245 & 0.95 \\
\hline 2008 & 1,232 & 10.97 & 2,448 & 1.24 & 566 & 1.15 & 1,516 & 0.61 & 636 & 0.71 & 6,398 & 0.99 \\
\hline 2009 & 1,180 & 10.89 & 2,369 & 1.20 & 534 & 1.09 & 1,425 & 0.57 & 556 & 0.63 & 6,064 & 0.94 \\
\hline 2010 & 1,192 & 10.75 & 2,397 & 1.37 & 523 & 1.01 & 1,34 & 0.51 & 595 & 0.66 & 6,047 & 0.93 \\
\hline 2011 & 1,354 & 10.99 & 2,867 & 1.66 & 585 & 1.14 & 1,448 & 0.56 & 543 & 0.61 & 6,797 & 1.06 \\
\hline 2012 & 1,329 & 10.98 & 2,624 & 1.55 & 576 & 1.14 & 1,571 & 0.62 & 571 & 0.66 & 6,671 & 1.07 \\
\hline 2013 & 1,291 & 10.94 & 2,524 & 1.53 & 596 & 1.20 & 1,526 & 0.62 & 554 & 0.67 & 6,491 & 1.07 \\
\hline 2014 & 1,150 & 10.75 & 2,181 & 1.35 & 567 & 1.15 & 1,425 & 0.60 & 509 & 0.63 & 5,832 & 0.98 \\
\hline 2015 & 1,224 & 10.88 & 2,249 & 1.41 & 545 & 1.11 & 1,355 & 0.58 & 455 & 0.58 & 5,828 & 1.00 \\
\hline 2016 & 1,203 & 10.86 & 2,124 & 1.34 & 519 & 1.06 & 1,261 & 0.55 & 458 & 0.59 & 5,565 & 0.96 \\
\hline 2017 & 1,016 & 10.57 & 1,965 & 1.26 & 484 & 0.99 & 1,153 & 0.51 & 368 & 0.48 & 4,986 & 0.87 \\
\hline 2018 & 1,069 & 10.66 & 2,002 & 1.31 & 459 & 0.95 & 1,027 & 0.46 & 325 & 0.43 & 4,882 & 0.87 \\
\hline
\end{tabular}

ASFR: Age-specific fecundity rate. Total LBs from mothers between 10 and 13 years/total population of resident adolescents of this age group, multiplied by 1,000 .

Romania has the highest fertility rates in Europe. In the age group of 10-14 years, in 2011 the pregnancy rate was $2.64 / 1,000$ and the birth rate was $1.41 / 1,000^{14}$.

The CLADEM ${ }^{15}$ study conducted in 14 countries in Latin America and the Caribbean demonstrated that specific data on pregnancy or abortion in girls aged $<14$ years existed only in El Salvador, with childbirths in $2 / 3$ of pregnancies. In the other countries, statistics were extracted from childbirths data and reflected only one subset of pregnancies in this age group ${ }^{15}$.

Pregnancy in girls aged 10-13 years is considered a crime of rape of vulnerable by Brazilian legislation ${ }^{6}$, regardless of consent. By adding the total number of cases, this study verified the existence of a contingent of sexual violence victims several times higher than shown in the official notification data.

Various motives can be inferred for the increase in the number of childbirths until the age of 13 years: difficulty to access public legal abortion services, late discovery of pregnancy, threats from the family or the rapist, religious beliefs, among others ${ }^{7}$. Furthermore, public health services that conduct elective pregnancy interruption are scarce and face barriers related to conscientious objection by health professionals and managers 4 .

In 2020, the total number of sexual violence cases was 66,123 with $57.9 \%$ corresponding to the rape of vulnerable. Gender inequality is evident, with $85.7 \%$ of female victims ${ }^{16}$. 

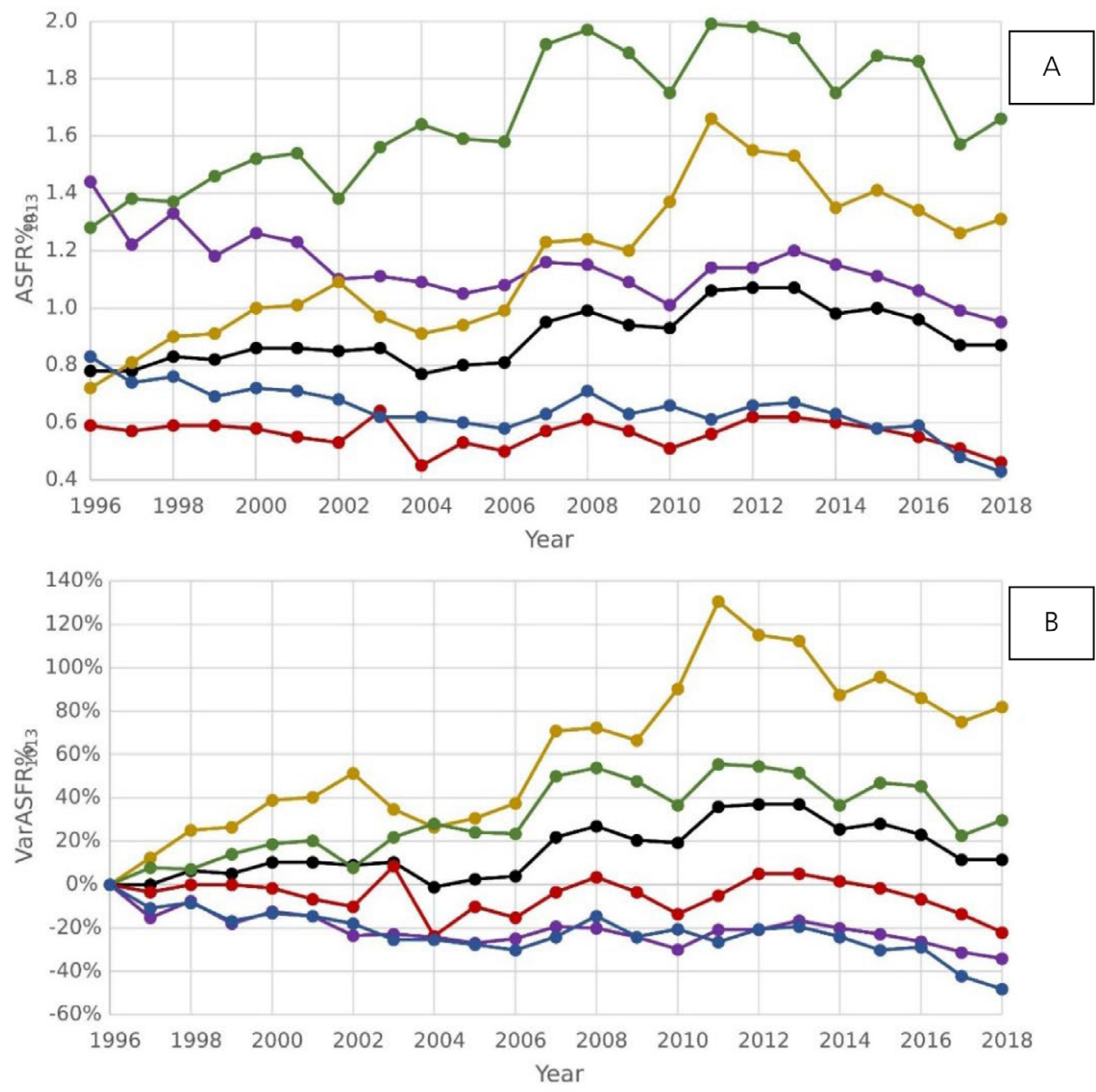

$\multimap$ Brazil $\rightarrow$ Mideast $\rightarrow$ Northeast $\multimap$ North $\rightarrow$ Southeast $\multimap-$ South

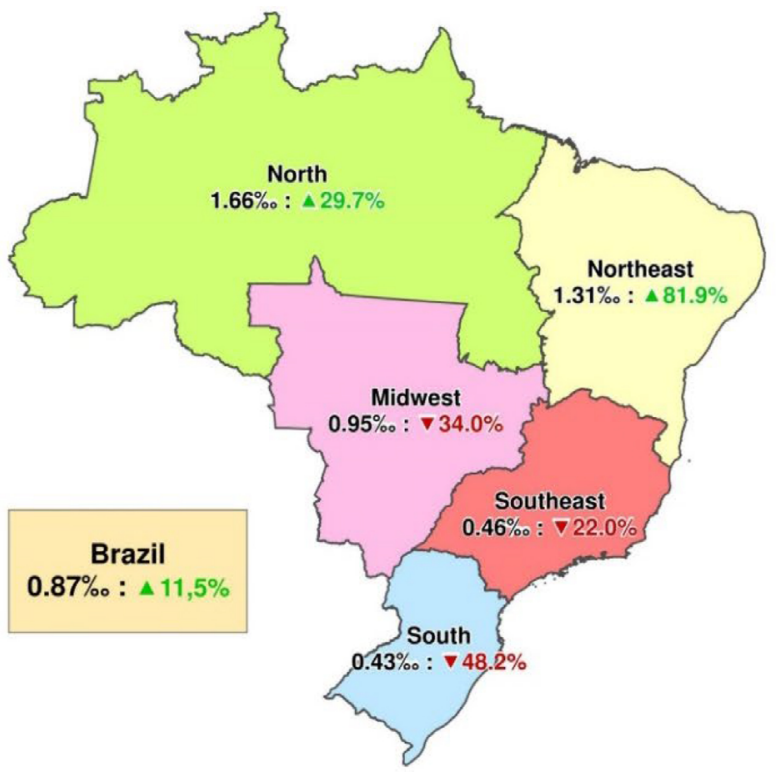

Figure 1. (A) Age-specific fecundity rate for interval 10-13 years old per region of Brazil (ASFR\% $\left.\%_{10-13 \text { reayear }}\right)$; (B) percentage variation of ASFR\% from 1996 to 2018 (VarASFR\% 10-13;reg;year); and (C) both rates 2018 for Brazil and its regions. 
Table 2. Annual distribution of the number of girls who became pregnant under 14 years of age and fertility rate (2012-2018).

\begin{tabular}{c|c|c|c|c|c|c} 
Year & $\begin{array}{c}\text { Female population } \\
\text { aged 10-13 years } \\
\text { (IBGE) }\end{array}$ & $\begin{array}{c}\text { Mother <14 } \\
\text { years at birth } \\
\text { (Group 1) }\end{array}$ & $\begin{array}{c}\text { Mother <14 years at } \\
\text { start of pregnancy } \\
\text { (Groups 1+2) }\end{array}$ & ASFR\%o & $\begin{array}{c}\text { RPRALAL\%o } \\
\text { RPRCentage not } \\
\text { included in ASFR }\end{array}$ \\
\hline 2012 & $6,240,822$ & 6,671 & 18,348 & 1.07 & 2.94 & 63.61 \\
\hline 2013 & $6,086,944$ & 6,491 & 18,908 & 1.07 & 3.11 & 65.59 \\
\hline 2014 & $5,958,212$ & 5,832 & 18,840 & 0.98 & 3.16 & 68.99 \\
\hline 2015 & $5,852,614$ & 5,828 & 18,008 & 1.00 & 3.08 & 67.53 \\
\hline 2016 & $5,789,131$ & 5,565 & 16,355 & 0.96 & 2.83 & 66.08 \\
\hline 2017 & $5,712,535$ & 4,986 & 15,230 & 0.87 & 2.67 & 67.42 \\
\hline 2018 & $5,638,556$ & 4,882 & 14,496 & 0.87 & 2.57 & 66.15 \\
\hline
\end{tabular}

ASFR: Age-specific fecundity rate. Total LBs from mothers between 10 and 13 years/total population of resident adolescents of this age group, multiplied by 1,000; RPRAL: Rate-related pregnancy rate according to legislation. Total LBs from mothers between 10 and 13 years added to total number of mothers who became pregnant aged 13 years but gave birth aged 14 years/total population of resident adolescents aged between 10 and 13 years, multiplied by 1,000 .

Souto et al..$^{5}$ compared the registers of rape of vulnerable with that of births from mothers aged $<14$ years and verified that only $4 \%$ were notified as sexual violence. A similar study ${ }^{17}$ showed notifications only in $1.3 \%$ in the age group of $10-13$ years.

The low notification by health professionals reveals that pregnancy in girls aged $<14$ years is not identified as resulting from sexual abuse, which highlights the invisibility of the problem ${ }^{5,17}$.

As limitations to our study, we highlight the following: insufficient filling in of official data available on SINASC/ DATASUS; impossibility to obtain the true number of adolescents who suffered abortion; difficulty to obtain the total number of stillbirths in adolescents; and utilization of two different data sources to estimate the resident population per age group (DATASUS and IBGE). This suggests that our data could be underestimated and the number of pregnancies at age $<14$ years could be even higher.

\section{CONCLUSION}

The ASFER increased $11.5 \%$ among girls aged $<14$ years in the less-developed regions of Brazil, which shows an association with socioeconomic factors and reveals the invisibility of rape of vulnerable in the country.

\section{AUTHORS" CONTRIBUTIONS}

DLMM: Conceptualization, Data curation, Formal analysis, Methodology, Writing - original draft, Writing - review \& editing. FRDM: Conceptualization, Writing - original draft, Writing review \& editing. IMSL: Data curation, Formal analysis, Writingoriginal draft. SRT: Data curation, Formal analysis, Methodology, Writing - original draft. JASR: Conceptualization, Data curation, Formal analysis, Methodology, Writing - original draft, Writing - review \& editing. FMS: Data curation, Formal analysis, Writing - original draft, Writing - review \& editing. NCPR: Conceptualization, Data curation, Formal analysis, Methodology.

\section{REFERENCES}

1. Monteiro DLM, Martins JAFS, Rodrigues NCP, Miranda FRD, Lacerda IMS, Souza FM, et al. Adolescent pregnancy trends in the last decade. Rev Assoc Med Bras (1992). 2019;65(9):120915. https://doi.org/10.1590/1806-9282.65.9.1209

2. Birhanu BE, Kebede DL, Kahsay AB, Belachew AB. Predictors of teenage pregnancy in Ethiopia: a multilevel analisys. BMC Public Health. 2019;(19):601. https://doi.org/10.1186/s12889019-6845-7

3. Fundo das Nações Unidas para a População. Situação da População Mundial 2019. Um trabalho inacabado: a busca por direitos e escolhas para todos e todas. [cited on Mar 28,
2021]. Available from: https://brazil.unfpa.org/pt-br/topics/ swop2019.

4. Jaramillo-Mejía MC, Chernichovsky D. Early adolescent childbearing in Colombia: time-trends and consequences. Cad Saude Publica. 2019;35(2):e00020918. https://doi. org/10.1590/0102-311X00020918

5. Souto RMCV, Porto DL, Pinto IV, Vidotti CCF, Barufaldi LA, Freitas MG, et al. Estupro e gravidez de meninas de até 13 anos no Brasil: características e implicações na saúde gestacional, parto e nascimento. Cienc Saúde Colet. 2017;22(9):2909-18. https://doi.org/10.1590/1413-81232017229.13312017 
6. Brasil. Presidência da República. Casa Civil. Subchefia para Assuntos Jurídicos. Lei $n^{\circ}$ 12.015, de 7 de agosto de 2009. Altera o Título VI da Parte Especial do Decreto-Lei n 2.848, de 7 dezembro 1940 - Código Penal, e art. $1^{\circ}$ da Lei n 8.072 , de 25 julho 1990, que dispõe sobre crimes hediondos, nos termos do inciso XLIII do art. $5^{\circ}$ da Constituição Federal e revoga a Lei $n^{\circ} 2.252$, de $1 \circ$ julho 1954 , que trata de corrupção de menores. Diário Oficial da União. [cited on Oct 29, 2021]. Available from: http://www.planalto.gov.br/ccivil_03/_ato20072010/2009/lei/l12015.htm

7. Maia LTS, Souza WV, Mendes ACG, Silva AGS. Use of linkage to improve the completeness of the SIM and SINASC in the Brazilian capitals. Rev Saúde Pública. 2017;51:112. https:// doi.org/10.11606/S1518-8787.2017051000431

8. Brasil. Ministério da Saúde. Tabnet - Demográficas e Socioeconômicas. [cited on Jul 13, 2020]. Available from: http://www2.datasus.gov.br/DATASUS/index. php? area $=0206 \& i d=6942 \& V O b j=h t t p: / /$ tabnet .datasus gov.br/cgi/deftohtm.exe?ibge/cnv/pop

9. Brasil. População residente - censo, contagens populacionais e projeções intercensitárias. [cited on Jul 13, 2020]. Available from: http://tabnet.datasus.gov.br/cgi/ibge/Popula_Censo_ Conta_Projecoes.pdf

10. Instituto Brasileiro de Geografia e Estatística. Projeções da população. [cited on Jul 13, 2020]. Available from: https:// www.ibge.gov.br/estatisticas/sociais/populacao/9109-projecaoda-populacao.html?=\& t=o-que-e

11. Martinez EZ, Roza DL. Ecological analysis of adolescent birth rates in Brazil: association with Human Development Index. Women Birth. 2020;33(2):e191-e198. https://doi.org/10.1016/j. wombi.2019.04.002
12. Instituto de Pesquisa Econômica e Aplicada. Desenvolvimento humano nas macrorregiões brasileiras. Brasília: PNUD, IPEA, FJP; 2016. [cited on Sep 03, 2020]. Available from: http://repositorio. ipea.gov.br/bitstream/11058/6217/1/Desenvolvimento\%20 humano\%20nas\%20macrorregi\%C3\%B5es\%20brasileiras. pdf.

13. Mathews TJ, Hamilton BE. Declines in births to females aged 10-14 in the United States, 2000-2016. NCHS Data Brief. 2018:(308):1-8. PMID: 29717976

14. Sedgh G, Finer LB, Bankole A, Eilers MA, Singh S. Adolescent pregnancy, birth, and abortion rates across countries: levels and recent trends. J Adolesc Health. 2015;56(2):223-30. https://doi.org/10.1016/j.jadohealth.2014.09.007

15. Chiarotti S, Páramo M, España M, Galli B, Ballestas C, Inoa $O$, et al. CLADEM. Child mothers: child pregnancy and forced child maternity in Latin America and the Caribbean. Asuncion: Latin American and Caribbean Committee for the Defense of Women's Rights; 2016. [cited on Sep 03, 2020]. Available from: https://cladem.org/wp-content/uploads/2016/03/ Executive-Summary-Child-Mothers-FINAL.pdf

16. Bueno S, Sobral I. Um estupro a cada 8 minutos. In: Fórum Brasileiro de Segurança Pública. Anuário Brasileiro de Segurança Pública; 2020. p. 132-8. [cited on Jul 28, 2020]. Available from: https://forumseguranca.org.br/wp-content/uploads/2020/10/ anuario-14-2020-v1-interativo.pdf

17. Silva AJC, Trindade RFC, Oliveira LLF. Presumption of sexual abuse in children and adolescents: vulnerability of pregnancy before 14 years. Rev Bras Enferm. 2020;73 Suppl 4:e20190143. https://doi.org/10.1590/0034-7167-2019-0143 